\title{
Plant Therapy sebagai Upaya Menjaga Kesehatan Mental di Masa Pandemi
}

\author{
Efforts to Maintain Mental Health with Plant Therapy in the Covid-19 Pandemic
}

\author{
Ainur Zafira Efendi ${ }^{*}$, Indah Purbasari ${ }^{2}$
}

Citation: Efendi, A.Z., Purbasari, I. Plant Therapy sebagai Upaya Men-

jaga Kesehatan Mental di Masa Pandemi. Buletin Pemberdayaan

Masyarakat dan Desa 2021, 1(1), 27-31. https://doi.org/10.21107/bpmd.v1i1.1 2022

Received: July, 2021

Accepted: August, 2021

Published: September, 2021

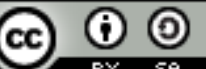

Copyright: (C) 2021 by the authors. Submitted for possible open access publication under the terms and conditions of the Creative Commons Attribution (CC BY SA) license (https://creativecommons.org/licens es/by-sa/4.0/).

\begin{abstract}
1 Psikologi, Universitas Trunojoyo Madura; Jl Raya Telang, Kamal Bangkalan Kode Pos 69162; 2 Ilmu Hukum, Universitas Trunojoyo Madura; Jl Raya Telang, Kamal Bangkalan Kode Pos 69162; *Correspondence: ainurzaf23@gmail.com;
\end{abstract}

\begin{abstract}
Abstrak: Pandemi Corona Virus Disease (Covid-19) menimbulkan berbagai dampak bagi kehidupan semua manusia dalam berbagai segi kehidupan. Dampak dari pandemi Covid-19 dapat mempengaruhi kondisi kesehatan psikologis seseorang. Kondisi psikologis atau masalah kesehatan mental yang dirasakan oleh masyarakat beberapa diantaranya adalah stress, kecemasan, dll. Pemicu dari stres di masa pandemi Covid-19 adalah banyaknya hal yang tidak direncanakan sebelumnya dan terjadi secara mendadak, seperti diterapkannya aturan bekerja dari rumah, pembelajaran menjadi sistem daring atau online, banyak pegawai yang harus dirumahkan, dll. Hal tersebut membuat banyak induvidu harus memutar otak agar kehidupan tetap berjalan seperti biasa. Sehingga tidak sedikit individu yang merasakan adanya gangguan pada kondisi mental mereka. Tujuan artikel ini sengaja dibuat agar dapat memberi manfaat bagi pembaca dari segi psikologis apa saja dampak dari pandemi bagi kesehatan mental serta salah satu terapi yang dapat diterapkan untuk meminimalisir dan menjaga kesehatan mental. Diharapkan artikel ini dapat memotivasi pembaca untuk tetap menjaga kesehatan mental dan agar dapat menerapkan pola hidup yang lebih sehat dan berkualitas, salah satunya adalah dengan menerapkan plant therapy.
\end{abstract}

Keywords: Pandemi, Kesehatan Mental, Plant Therapy

\begin{abstract}
The corona virus disease pandemic (Covid-19) had various impact on the lifes of all humans in various aspects of life. Effect of the Covid-19 pandemic can affect a person's psychological health condition. Some of the psychological conditions or mental health problems that society experiences are stress, anxiety, etc. The triggers of stress during the covid-19 pandemic are a lot of things that weren't planned before and happen suddenly, such as house rules are enforced, study becomes an online or online system, many employees are to be sent home, dil. That makes many individuals have to twist the brain to keep life running its course. So there are very few individuals who sense any disturbances to their mental state. The purpose of this article is intended to benefit psychological readers in what ways will the pandemic affect mental health as well as one of the therapies that can be used to minimize and maintain mental health. It is hoped that this article will motivate readers to keep me mentally healthy and to adopt healthier, better living patterns, one of which is applying plant therapy.
\end{abstract}

Keywords: Pandemic, Mental Health, Plant Therapy

\section{PENDAHULUAN}

Pada akhir tahun 2019 tepatnya pada bulan Desember dunia digemparkan dengan munculnya wabah virus baru yang berbahaya dan mematikan. Virus ini pertama kali dilaporkan tepatnya di Kota Wuhan, China. Pada pertengahan bulan Maret 2020, WHO mengumumkan Covid-19 sebagai pandemi. Di Indonesia Corona Virus Disease (Covid-19) mulai muncul dan dinyatakan sebagai kasus pertama pada bulan Maret 2020. Berbagai upaya dilakukan oleh pemerintah sejak awal adanya Corona Virus Disease (Covid-19) di Indonesia, mulai dari pemberlakuan social distancing, memberlakukan karantina mandiri, anjuran untuk menggunakan masker ketika berada di luar rumah, mencuci tangan 
dengan sabun dan menggunakan handsanitizer. Aturan-aturan tersebut diberlakukan untuk mencegah penyebaran Covid-19 agar segera dapat dihentikan mengingat bahwa kasus positif yang terus meningkat setiap hari.

Disisi lain, pandemi juga merubah tatanan kehidupan masyarakat dari berbagai aspek mulai dari segi psikologis, ekonomi, sosial, dan pendidikan. Dimana semua kegiatan dianjurkan untuk dilakukan di rumah, sehingga tidak banyak kegiatan produktif yang dapat dilakukan karena keadaan yang terjadi sangat tiba-tiba dan masyarakat saat itu belum terbiasa, sehingga hal tersebut juga berdampak pada kesehatan mental masyarakat. Pada kondisi pandemi saat ini, banyak masyarakat yang mengalami peningkatan stress dan masalah kondisi psikologis lainnya, baik dari kondisi psikologis bawaan ataupun bukan. Hal tersebut membuat banyak masyarakat mencari cara mengatasi kondisi tersebut, salah satunya adalah dengan menerapkan plant therapy untuk mereduksi tingkat stress. Bukan hanya itu, manfaat plant therapy juga dapat berpengaruh pada beberapa kondisi psikologis lainnya.

Menurut Yosep (dalam Rini, dkk, 2019) Terapi berkebun adalah salah satu bentuk terapi aktif. Terapi berkebun telah menjadi bagian penting karena dapat meningkatkan kesehatan tubuh, pikiran dan semangat serta kualitas hidup. Terapi ini merupakan terapi yang unik karena dapat membuat individu berhubungan dengan makhluk hidup yaitu tumbuh-tumbuhan. Linden (dalam Waibi, 2016) Horticultural Therapy adalah sebuah proses melalui menanam, aktifitas berkebun dan kedekatan dengan alam yang digunakan sebagai media dalam program terapi dan rehabilitasi. Program berkebun ini menawarkan sebuah kesempatan untuk relaksasi dan membebaskan diri dari lingkungan sosial yang kasar.

Menurut Rini, dkk (2019) Hasil yang didapatkan yaitu adanya peningkatan harga diri klien sebelum dan sesudah dilaksanakan kegiatan Plant Therapy dengan pembentukan kelompok-kelompok kecil yang dapat dilihat dari tanda dan gejala klien yaitu klien lebih terbuka terhadap dirinya sendiri (memiliki kemampuan dalam hal berkebun) dan akan meneruskan kegiatan berkebun, klien mencoba untuk lebih menerima dirinya sendiri, klien tampak tertarik dan antusias untuk mengikuti terapi berkebun, klien tampak sudah mencoba untuk saling membantu dalam berkebun dan klien mengatakan hasil kebun akan digunakan bersama warga panti lainnya. Menurut Yanuarsari, dkk (2020) Hasil penelitian, menunjukan bahwa terjadi peningkatan kecerdasan naturalis setelah menggunakan metode bercocok tanam. Menurut Magfirah dan Alifariki (2018) Hasil analisis bivariat pada empat pertemuan menunjukkan bahwa ada pengaruh terapi berkebun terhadap perubahan tekanan darah sistolik diastolik. Kesimpulan dari penelitian ini adalah bahwa terapi berkebun efektif untuk menormalkan tekanan darah lansia dengan hipertensi, terapi berkebun sebagai salah satu alternatif terapi nonfarmakologi yang dapat dilakukan secara mandiri atau bersama tanpa efek samping. Menurut Salitonga, dkk (2017) Hasil analisis menunjukkan bahwa adanya peningkatan self-efficacy pada masing-masing partisipan, sebelum dan setelah mengikuti intervensi self-efficacy. Ini menunjukkan bahwa partisipan lebih yakin untuk menjalankan tugas yang diberikan, mampu menghadapi situasi-situasi yang kurang mendukung serta menemukan solusi atas permasalahan yang terjadi pada kehidupan sehari-hari.

Artikel ini sengaja dibuat agar dapat memberi manfaat bagi pembaca dari segi psikologis apa saja dampak dari pandemi bagi kesehatan mental serta salah satu terapi yang dapat diterapkan untuk meminimalisir dan menjaga kesehatan mental. Diharapkan artikel ini dapat memotivasi pembaca untuk tetap menjaga kesehatan mental dan agar dapat menerapkan pola hidup yang lebih sehat dan berkualitas, salah satunya adalah dengan menerapkan plant therapy.

\section{DISKUSI DAN PEMBAHASAN}

Pandemi terjadi ketika adanya jenis penyait baru yang muncul kemudian menginfeksi dan menyebar dari manusia ke manusia dengan cara yang cepat serta berkelanjutan. Seringkali karakteristik virus tidak terdefinisi dengan baik, dan tingkat terjangkitnya virus tergantung pada kekebalan imunitas tubuh individu terhadap virus tersebut, serta kondisi 
kesehatan, usia, dan komorbiditas dari orang yang terinfeksi. WHO secara resmi mendeklarasikan virus corona (COVID-19) sebagai pandemi, yang berarti bahwa virus ini telah menyebar di seluruh penjuru dunia.

Di Indonesia sendiri Corona Virus Disease (Covid-19) mulai muncul dan dinyatakan sebagai kasus pertama pada bulan Maret 2020 tepatnya di daerah Depok, Jawa Barat dan pada tanggal 18 Juli 2020 dibuktikan bahwa kasus terindikasi positif Corona Virus Disease (Covid-19) sebanyak 84.882 jiwa penduduk dan angka terjangkitnya virus ini masih terus bertambah hingga saat ini. Hal ini menjadikan Indonesia masuk ke dalam daftar negara yang darurat Covid-19.

Sejak ditemukannya kasus Covid di Indonesia, pemerintah telah banyak berupaya untuk mencegah sebaran virus yang semakn luas, salah satu diantaranya adalah dengan pemberlakuan social distancing, melakukan karantina mandiri, anjuran untuk menggunakan masker ketika berada di luar rumah, mencuci tangan dengan sabun dan menggunakan handsanitizer. Hanya saja saat awal munculnya kasus Corona di Indonesia masih banyak masyarakat yang berlawanan dengan pemerintah, sehingga kurang aware terhadap kondisi saat itu. Hal ini semakin mendukung tingkat sebaran virus yang semakin meluas.

Dari data terkait kasus posistif Covid-19 yang semakin hari terus melonjak dan tersebar luas, sehingga pemerintah mengambil tindakan untuk melakukan PSBB dan berkegiatan yang awalnya dilakukan secara tatap muka (bekerja, melakukan pembelajaran, dll) kini harus dilakukan dari rumah atau secara online.

\section{Dampak pandemi bagi kesehatan mental}

Pandemi Covid-19 tak hanya berdampak pada fisik penderitanya, tetapi juga berdampak pada kondisi ekonomi, sosial, pendidikan dan terutama pada kondisi kesehatan mental baik orang yang terjangit ataupun tidak. Banyak individu yang harus memutar otak untuk menyesuaikan diri pada kondisi pandemi. Hal tersebut menjadi stressor tambahan untuk individu, baik individu normal maupun yang memiliki kekurangan dari segi kesehatan mentalnya.

Pada kondisi terdesak atau dirasa kurang aman, maka tingkat agresi pada individu tersebut menjadi tinggi. Hal tersebut dikarenakan rasa stress yang belum terselesaikan dengan baik, baik stress yang terjadi karena stimulus eksternal ataupun internal dari individu tersebut.

Selain tingkat stress yang semakin tinggi, tidak sedikit juga beberapa diantaranya mengalami kecemasan, terutama kecemasan akan terjangkitnya virus Covid-19. Sehingga melakukan melakukan proteksi ekstra yang berlebihan dan menjadi sering berpikiran negatif atau merasa ragu pada individu lain. Hal ini juga dapat berpengaruh terhadap pola bersosialnya dan jika terus berlanjut tidak menutup kemungkinan juga akan dapat mengalami OCD.

\section{Menjaga kesehatan mental dengan Plant therapy}

Untuk menjaga kesehatan mental di masa pandemi, salah satu jenis kegiatan yang dapat dilakukan adalah dengan terapi lingkungan atau palnt therapy untuk individu dengan stress atau depresi. Tujuan dari terapi ini untuk mengajarkan individu agar dapat memelihara segala sesuatu dan meningkatkan hubungan yang lebih intim antar individu.

Plant therapy atau terapi lingkungan dinilai mampu menurunkan tingkat stress ataupun depresi yang dialami oleh individu. Aktivitas berkebun membantu individu lebih dapat merasakan emosi dan moods yang lebih positif setelah melakukan aktivitas tersebut. Individu menjadi merasa lebih tenang tingkat stress yang dialami menjadi lebih berkurang daripada sebelum menerapkan terapi tersebut.

Selain dapat mengurangi tingkat stress atau depresi pada individu, terapi ini juga sering diterapkan pada lansia maupun individu dengan kasus harga diri rendah, dengan menanam tanaman, membuat individu merasakan rasa tanggung jawab dan dapat meningkatkan harga diri serta menjadi lebih percaya diri. Mengetahui mereka bertanggung jawab untuk memelihara dan merawat tumbuhan hidup membuat individu merasa lebih produktif dan merasa termotivasi. Sehingga membuat individu merasa tenang dan menjadi lebih terbuka. 
Tidak hanya itu, plant therapy juga merupakan salah satu terapi yang diterapkan pada anak-anak yang berkebutuhan khusus atau anak-anak yang mengalami gannguan atensi untuk melatih mereka agar menjadi lebih fokus pada sesuatu. Terapi ini dapat menurunkan gejala gangguan atensi pada anak secara signifikan dibandingkan dengan terapi lainnya.

\section{KESIMPULAN}

Pada akhir tahun 2019 tepatnya pada bulan Desember dunia digemparkan dengan munculnya wabah virus baru yang berbahaya dan mematikan dan pada pertengahan bulan Maret 2020, WHO mengumumkan Covid-19 sebagai pandemi. Di Indonesia sendiri Corona Virus Disease (Covid-19) mulai muncul dan dinyatakan sebagai kasus pertama pada bulan Maret 2020. Pandemi terjadi ketika adanya jenis penyait baru yang muncul kemudian menginfeksi dan menyebar dari manusia ke manusia dengan cara yang cepat serta berkelanjutan. Dari data terkait kasus posistif Covid19 yang semakin hari terus melonjak dan tersebar luas, sehingga pemerintah mengambil tindakan untuk melakukan PSBB dan berkegiatan yang awalnya dilakukan secara tatap muka (bekerja, melakukan pembelajaran, dll) kini harus dilakukan dari rumah atau secara online.

Pandemi Covid-19 tak hanya berdampak pada fisik penderitanya, tetapi juga berdampak pada kondisi ekonomi, sosial, pendidikan dan terutama pada kondisi kesehatan mental baik orang yang terjangit ataupun tidak. Tingginya tingkat agresi pada individu dikarenakan yang belum terselesaikan dengan baik, baik stress yang terjadi karena stimulus internal ataupun eksternal. Selain stress, individu juga dapat mengalami kecemasan dan menjadi berlebihan dalam melakukan sesuatu agar dapat memenuhi rasa aman yang dinginkan. Hal ini juga dapat memicu penyakit mental lainnya.

Untuk menjaga kesehatan mental di masa pandemi, salah satu jenis kegiatan yang dapat dilakukan adalah dengan terapi lingkungan atau palnt therapy untuk individu dengan stress atau depresi. Plant therapy atau terapi lingkungan dinilai mampu menurunkan tingkat stress ataupun depresi yang dialami oleh individu dan membantu individu lebih dapat merasakan emosi dan moods yang lebih positif. Terapi ini juga sering diterapkan pada lansia maupun individu dengan kasus harga diri rendah, dengan menanam tanaman, membuat individu merasakan rasa tanggung jawab dan dapat meningkatkan harga diri serta menjadi lebih percaya diri.

Selain itu, plant therapy juga merupakan salah satu terapi yang diterapkan pada anak-anak yang berkebutuhan khusus atau anak-anak yang mengalami gangguan atensi untuk melatih mereka lebih fokus pada sesuatu. Terapi ini dapat menurunkan gejala gangguan atensi pada anak secara signifikan dibandingkan dengan terapi lainnya.

\section{SARAN}

Dalam kegiatan sehari-hari individu atau masyarakat harus mematuhi protokol kesehatan yang sesuai dengan anjuran pemerintah. Selain masyarakat juga harus bisa menjaga kesehatan agar bisa mengahadapi situasi pandemi ini dan agar terhindar dari berbagai penyakit. Hal ini menjadi penting ketika masa pandemi ini berakhir dan kemudian kita semua dapat hidup dengan sehat. Selain itu pada masa pandemi ini juga mempengaruhi kondisi psikologis seseorang seperti stres dan masalah kesehatan mental lainnya, untuk mengatasi atau mengurangi masalah kesehatan mental, masyarakat dapat menerapkan terapi lingkungan atau plant therapy sebagi salah satu terapi yang dapat dilakukan dirumah. 


\section{DAFTAR RUJUKAN}

Aditama. F, Budiyanto. 2021. Penerapan sistem hidroponik wick system untuk meningkatkan keterampilah bercocok tanam hidroponik anak cerebral palsy. Jurnal Pendidikan Khusus. Diakses pada tanggal 11 Juli 2021

Magfirah, Alifariki. L. O. 2018. Pengaruh terapi berkebun terhadap perubahan tekanan darah pada lansia dengan hipertensi di panti sosial tresna werdha minaula kendari. Journal Of Islamic Nursing. Vol 3, No. 2 Diakses pada tanggal 18 Juli 2021

Mardiyanti. R. E, Praseyto. Y. B. 2012.depresi pada usia lanjut: implementasi terapi lingkungan di panti werdha. Jurnal Keperawatan. Vol 3. 204-215 Diakses pada tanggal 19 Juli 2021

Pane. M. M. 2013. Psikologi “hijau” (green psychology) sebagai alternatif untuk peningkatan kesejahteraan psikologis masyarakat perkotaan. Humaniora. Vol 4. 411-421 Diakses pada tanggal 18 Juli 2021

Pertiwi. R, Notriawan. D, Wibowo. R. D. 2020. Pemanfaatan tanaman obat keluarga (toga) meningkatkan imunitas tubuh sebagai pencegahan covid-19. Jurnal Ilmiah Pengembangan dan Penerapan IPTEKS. Vol 18. 110-118. Diakses pada tanggal 18 April 2021.

Rini. P. S, Romadoni. S, Dekawaty. A. 2019. Plant therapy untuk meningkatkan harga diri rendah pada klien harga diri rendah di panti rehabilitasi pengemis, gelandangan dan orang terlantar (PR-PGOT). Vol 2. No. 1 Diakses pada tanggal 11 Juli 2021

Silitonga. A. N, Satiadarma. M. P, Risnawaty. W. 2017. Penerapan hortiluktura terapi untuk meningkatkan self-efficiency pada lansia. Jurnal Muara Ilmu Sosial, Humaniora, dan Seni. Vol 1. 399-405 Diakses pada tanggal 11 Juli 2021

Tim Yayasan Inisiatif Indonesia Biru Lestari (Waibi). 2016. Pengaruh horticulture therapy terhadap tingkat agresi narapidana: sebuah analisa rasch model. Journal of Dedicators Community. Vol. 1, No. 1 Diakses pada tanggal 18 Juli 2021

Welly. W, Supatra. S. 2019. Penghijauan sebagai terapi penyembuhan untuk orang dengan gangguan mental. Jurnal STUPA (Sains, Teknologi, Urban, Perancangan Arsitektur). Vol 1. 1211-1220. Diakses pada tanggal 18 April 2021.

Yanuarsari. R, Octrianty. E, Nurmilah. U. 2020. Penerapan metode bercocok tanam untuk meningkatkan kecerdasan naturalis anak. Indonesian Journal Of Adult and Community Education. Vol 2, No. 1 Diakses pada tanggal 18 Juli 2021 